\title{
KAJIAN KARAKTERISTIK, PERILAKU DAN FAKTOR PENDORONG PETANI MUDA TERLIBAT DALAM AGRIBISNIS PADA ERA PASAR GLOBAL
}

\author{
ELLY RASMIKAYATI ${ }^{1,2}$, IWAN SETIAWAN ${ }^{1}$, BOBBY RACHMAT SAEFUDIN ${ }^{2}$ \\ ${ }^{1}$ Fakultas Pertanian, Universitas Padjadjaran \\ ${ }^{2}$ Pusat Riset Pangan Berkelanjutan DRPM UNPAD \\ Email: e.rasmikayati@unpad.ac.id; elly.agri@yahoo.co.id
}

\begin{abstract}
ABSTRAK
Pasar produk pertanian telah berubah secara signifikan, yang tadinya bersifat tradisional, sekarang sudah lebih modern dan bersifat global. Demikian juga dengan petaninya, yang tadinya digambarkan petani Indonesia adalah sudah pada tua dan jenuh, sepertinya tidak sepenuhnya benar. Terdapat proses regenerasi, ada kecenderungan bahwa petani muda yang terlibat di agribisnis sudah mulai meningkat kuantitasnya. Tujuan penelitian ini adalah untuk mengetahui: (1) Karakteristik petani muda pelaku agribisnis, (2) Perilaku beragribisnis petani muda, dan (3) Faktor-faktor yang mendorong mereka untuk terjun di bidang agribisnis. Metode penelitian yang dilakukan adalah survey yang diperkaya dengan FGD. Ukuran sampel sebanyak 280 orang yang berasal dari 3 lokasi terpilih di Jawa Barat. Analisis data yang digunakan adalah statistik deskriptif, tabulasi silang dan korelasi. Hasil penelitian menunjukan bahwa: (1) Petani muda pelaku agribisnis umumnya berpendidikan lebih tinggi, dan berpengalaman tidak hanya di bidang pertanian tapi juga bidang nonpertanian, (2) Perilaku agribisnis petani muda, walaupun masih memiliki kelemahan pada sisi kualitas dan belum berdaya saing, mereka umumnya sudah melaksanakan agribisnis yang lebih modern, dan (3) Terdapat beberapa faktor utama yang mendorong para petani muda untuk terlibat di bidang agribisnis, diantaranya faktor lembaga penyuluhan, perusahaan agribisnis, komunitas dan dukungan keluarga.
\end{abstract}

Kata kunci : petani muda, pasar global, perilaku agribisnis

\section{PENDAHULUAN}

Keberlanjutan sektor pertanian menghadapi ancaman yang serius dengan berkurangnya jumlah petani. Berdasarkan angka jumlah petani pada Sensus Pertanian 2003 dan 2013, jumlah rumah tangga tani berkurang sebanyak lima juta. Selain itu, masalah lain yang kini dihadapi adalah tuanya usia petani. Berdasarkan data Sensus Pertanian 2013, struktur usia petani didominasi oleh petani tua dengan tingkat pendidikan rendah, sebanyak 60,8 persen usia petani di atas 45 tahun dengan 73,97 persen berpendidikan setingkat SD dan akses terhadap teknologi rendah. Melihat kondisi tersebut, regenerasi di sektor pertanian menjadi penting dalam rangka membangun pertanian terutama di era pasar global saat ini.

Mewujudkan generasi pelaku-pelaku pertanian di era pasar global yang berkualitas dan berdaya saing global bukanlah pekerjaan mudah, tetapi melihat realitas kondisi sektor pertanian saat ini yang sebagian besar sumberdaya manusianya tua, dinilai rendah oleh 
Kajian Karakteristik, Perilaku dan Faktor Pendorong Petani Muda

Terlibat dalam Agribisnis pada Era Pasar Global

ELLY RASMIKAYATI, IWAN SETIAWAN, BOBBY RACHMAT SAEFUDIN

generasi dan ditinggal oleh tenaga-tenaga muda berkualitas, maka regenerasi menjadi keharusan. Tantangannya adalah lompatan kebutuhan pangan, ekonomi masa depan (blue economy), dinamika ilmu pengetahuan dan teknologi, inovasi agribisnis terintegrasi, kompleksitas permasalahan dalam sistem pertanian (terutama climate change) dan era keterbukaan yang diwarnai dengan tingkat persaingan yang sangat ketat. Tidak terbayangkan, bagaimana jadinya jika SDM sektor pertanian yang tua dibiarkan berjuang menghadapi cepatnya dinamika teknologi dan kompleksnya permasalahan, serta bersaing secara terbuka dengan pelaku-pelaku pertanian bertalenta dari berbagai negara.

Dengan kondisi seperti itu, sebagus dan secanggih apapaun upaya, kebijakan dan teknologi untuk melindungi dan memberdayakan mereka, tetap akan sulit terwujud, sulit berkualitas dan berdaya saing. Jika saat ini saja pangsa dan citra produk para petani (di pasar domestik) sudah mulai tersisih oleh impor, apalagi nanti dalam era pasar global dan era konektivitas.

Namun demikian, angin segar saat ini sedang berhembus dengan kehadiran pelaku-pelaku muda agribisnis yang terdidik dan berkeahlian di pedesaan.
Mereka adalah pemuda-pemuda yang lama merantau ke perkotaan atau ke luar daerahnya, namun karena berbagai faktor mereka kembali ke desa, baik untuk bekerja di pedesaan maupun berwirausaha pertanian, perikanan, peternakan, perkebunan dan kehutanan. Mereka ada yang bergerak dalam usahatani atau produksi (on-farm), penyediaan input produksi (up-stream), pelayanan dan pemberdayaan (supporting), agrokreatif (agrowisata, ekowisata, desa wisata) maupun penanganan pascapanen, pendistribusian, pemasaran dan pengolahan hasil (down-stream). Termasuk wirausaha agroindustri kreatif (kerajinan, kuliner, kesenian) skala mikro, kecil dan menengah. Pada umumnya, pelaku muda agribisnis eksis di setiap zona produksi pertanian di Indonesia, namun fenomenanya lebih terlihat nyata di Pulau Jawa, terutama di zona agroekosistem dataran tinggi yang berbasis komoditas hortikultura (BPS, 2012). Berdasarkan hal-hal tersebut, maka tujuan penelitian ini adalah untuk mengetahui: (1) Karakteristik petani muda pelaku agribisnis; (2) Perilaku beragribisnis petani muda; dan (3) Faktor-faktor yang mendorong mereka untuk terjun di bidang agribisnis. 
Jurnal Pemikiran Masyarakat Ilmiah Berwawasan Agribisnis. 2017. 3(2): 134-149

\section{TINJAUAN PUSTAKA}

\section{Petani Muda}

Sebagai sebuah proses dan aktivitas, regenerasi (regeneration) bukan sekedar penting, tetapi merupakan tuntutan sejarah yang tidak terelakan. Regenerasi merupakan indikator atau kriteria keberlanjutan dan menjadi salah satu karakteristik dari sistem yang dinamis, yakni sistem menghasilkan diri (selfgenerating), yang berarti semua komponen sistem dihasilkan oleh proses-proses yang berlangsung di dalam jejaring sistemnya (Capra, 2002). Regenerasi merupakan satu kesatuan dengan pembatasan diri (selfbounded) dari jaringannya dan pelestarian diri (self-perpetuating) atau proses-proses yang berjalan sepanjang waktu. Dalam pandangan Don Weaver (2002), regenerasi erat kaitannya dengan pembaharuan, keberlanjutan, kesehatan, lingkungan, masa depan bumi dan hijau (green). Sebagai proses, regenerasi penting dan terjadi (secara alami maupun direncanakan) karena tuanya umur generasi yang ada (aging), kerusakan, kemunduran, kegelapan, kejenuhan. Oleh Glauben, et al (2003), regenerasi didefinisikan sebagai pergantian (succession) sesuatu yang lama oleh yang baru yang lebih baik; yang menurut Cooley praktiknya dapat terjadi dalam diri (self), komunitas (community) dan masyarakat (society).

Regenerasi (succession) merupakan fragmen perilaku yang mempengaruhi keputusan dan strategi rumah tangga tani. Regenerasi bisnis keluarga (seperti pertanian) dari satu generasi ke generasi berikutnya dipertimbangkan sebagai sebuah momentum yang berdampak jangka panjang terhadap bisnis. Regenerasi dalam rumah tangga tani itu ada yang didesain secara eksplisit (berbasis regenerasi) dan ada yang berjalan apa adanya (berbasis kelompok). Investasi dan keputusan restrukturisasi bisnis secara internal juga senantiasa mempertimbangkan regenerasi (Glauben, et al, 2004). Menurut Inwood dan Sharp (2009), regenerasi merupakan isu krusial dalam relasi pedesaan-perkotaan, regenerasi memainkan peranan penting dalam keuletan dan adaptasi usaha, serta kunci strategis bagi rumah tangga dalam mengelola risiko dan perluasan usaha. Pertanian merupakan sektor khusus yang regenerasinya banyak dijadikan pembanding sektor-sektor lainnya.

Perspektif psikologi (Rakhmat, 1999) memandang bahwa regenerasi merupakan kunci keberlanjutan. Regenerasi selalu menjadi prioritas strategi yang dirumuskan oleh generasi-generasi sebelumnya yang 
Kajian Karakteristik, Perilaku dan Faktor Pendorong Petani Muda

Terlibat dalam Agribisnis pada Era Pasar Global

ELLY RASMIKAYATI, IWAN SETIAWAN, BOBBY RACHMAT SAEFUDIN

menyadari dan memahami arti pentingnya.

Asumsinya, semakin tua umur suatu generasi, maka semakin melemah daya biologisnya, psikologisnya, kepekaannya, daya ciptanya, motivasi berprestasinya, daya juang dan optimismenya. Capra (2002) menegaskan, tanpa regenerasi tidak akan tercipta dinamisasi, biofeedback dan keberlanjutan. Tanpa regenerasi, seseorang, komunitas, bangsa dan negara bisa mati dalam satu generasi. Ditegaskan oleh Capra, Simonton dan Creighton bahwa regenerasi tidak terjadi dengan sendirinya, tetepi diciptakan, diinisiasi, dikreasi dan diinovasi. Boleh jadi, regenerasi bersifat reproduktif (biologis atau budaya), namun secara alamiah, tuntutan regenerasi selalu penuh harapan, lebih baik, produktif, maju, adil, terintegrasi dan menjamin keberlanjutan sosial, ekonomi dan ekologis (Hawwa, 2007).

Perspektif ekologi dalam (deep ecology) memandang regenerasi sebagai salah satu prasyarat keberlanjutan. Menurut Smith (2007), regenerasi merupakan isu strategis yang menjadi kajian berbagai bidang ilmu, termasuk sosiologi pedesaan, ilmu lingkungan dan ilmu perencanaan pembangunan. Regenerasi bermakna kelahiran kembali, kehadiran kembali, kemunculan kembali, kebangkitan kembali dan pembangunan kembali, setelah fase senja (aging), menurun (declined), suram, tenggelam dan gelap (the dark). Istilah regenerasi tidak jarang tersamarkan oleh konsep revitalisasi (bringing new life to) atau renaissance (being reborn). Pada mahluk hidup, regenerasi identik dengan kelahiran kembali, kemunculan kembali dan kebangkitan kembali. DCLG (2012) membagi dua jenis regenerasi, yakni regenerasi proses (from inputs through activities to outputs, outcomes, impacts and value) dan regenerasi produk. Zukin (1995) menegaskan bahwa regenerasi merupakan proses kompleks, menyangkut aspek sosialbudaya, ekonomi, politik, fisik-teknis, kelembagaan dan ekologis.

Perspektif kebijakan publik memandang regenerasi sebagai "sebuah proses holistik membalik kembali (reversing) ekonomi, sosial dan fisikal yang sudah merosot, mundur atau runtuh" (DCLG, 2010). Terkait dengan pemerintahan, regenerasi dijadikan sebagai komitmen bersama untuk membuat asetaset dan masyarakat menjadi lebih baik. Regenerasi dapat menolong penyesuaian peran-peran baru dan perbaikan distribusi peluang dan kesejahteraan. Selain itu, regenerasi diyakini dapat memperbaiki keadilan sosial dan mereduksi tekanan komunitas. Tegasnya, regenerasi memainkan peranan penting dalam 
Jurnal Pemikiran Masyarakat Ilmiah Berwawasan Agribisnis. 2017. 3(2): 134-149

komunitas, dengan menumbuhkan harapan dan kebersamaan. Pertemuan Regenerasi Nasional 14 Juli 2010 di Inggris menyepakati bahwa esensi regenerasi adalah menghilangkan kesenjangan, terutama di pedesaan (sub-district level) atau dalam kelompok sosial (kemiskinan, pengangguran). Regenerasi memungkinkan untuk diinisiasi dan diintervensi oleh pemerintah atau pelaku terkait, terutama di tingkat lokal.

DCLG (2012) meyakini bahwa regenerasi dapat menghilangkan hambatanhambatan pertumbuhan ekonomi, membantu para pemimpin lokal untuk menguatkan komunitasnya dan mendorong masyarakat untuk lebih produktif. Dalam kerangka yang lebih luas, regenerasi merupakan kunci sukses keberlanjutan (kondisi yang kondusif dan sehat). Regenerasi tidak hanya penting bagi keberlanjutan individu-individu dan komunitas-komunitas, tetapi juga bagi negara. Seperti disebutkan Smith (2007), DCLG juga mengakui keberagaman konten dan konteks regenerasi, sehingga memberi terminologi alternatif untuk regenerasi sistem politik dan pemerintahan negara, yakni reformasi dan desentralisasi. DCLG menegaskan bahwa regenerasi bisa berbeda antara komunitas, antar kawasan dan antar negara. Secara mikro, regenerasi juga terjadi dalam satu rumah tangga, seperti regenerasi dalam rumah tangga tani (Mishra dan Hisham, 2007), bahkan dimasukan sebagai salah satu bagian dari manajemen risiko.

Terdapat beberapa pola (model) regenerasi pelaku pembangunan yang diterapkan di masyarakat, institusi, pemerintahan, sektor dan lainnya. Regenerasi ada yang dilakukan secara terencana dan ada yang tidak terencana (Mishra dan Hisham, 2007). Ada yang prosesnya berjalan lamban (evolutif) dan ada yang berjalan cepat (revolutif). Menurut Dumas, et al (1995), regenerasi (suksesi) yang berjalan secara terencana biasanya berlangsung secara bertahap (gradual). Pada kasus regenerasi pertanian, proses regenerasi terbagi menjadi empat tahap, yakni tahap inkubasi, tahap memilih, tahap pengelolaan bersama dan tahap meninggalkan yang sebelumnya. Proses regenerasi ada yang berjalan secara gradual dan ada yang cepat. Beberapa pendekatan regenerasi yang dilakukan secara cepat dan terencana adalah: (1) mendatangkan tenaga-tenaga yang lebih muda dan terlatih dari luar negeri, luar daerah atau dari perkotaan ke pedesaan; (2) membalik tenaga-tenaga terdidik yang lama tinggal (sekolah, bekerja, berwirausaha) di perkotaan atau di luar 
Kajian Karakteristik, Perilaku dan Faktor Pendorong Petani Muda

Terlibat dalam Agribisnis pada Era Pasar Global

\section{ELLY RASMIKAYATI, IWAN SETIAWAN, BOBBY RACHMAT SAEFUDIN}

negeri ke daerah atau ke negara asalnya (brain gain); dan (3) pemberdayaan dan penyuluhan terhadap generasi petani.

Regenerasi merupakan isu krusial, baik dalam ruang perkotaan maupun pedesaan. Bukan hanya memainkan peranan penting dalam keberlanjutan dan penyesuaian usaha, juga merupakan kunci dalam mengelola risiko dan perluasan usahatani. Inwood dan Sharp (2009) mengidentifikasi dua pendekatan regenerasi, yakni tipe yang digerakkan pihak luar (adopsi) dan tipe yang digerakkan masyarakat sendiri (adaptasi). Tipe pertama, oleh Ashok, et al (2007) disebut regenerasi terencana (base succession) dan kedua disebut regenerasi tanpa rencana (no succession plan). Tipe adopsi digerakkan oleh fasilitator, konselor, konsultan dan penyuluh (pemerintah, swasta maupun swadaya), sedangkan tipe adaptasi terbagi dalam empat tipe. Pertama, pemekar (usaha perluasan usahatani melalui peningkatan lahan). Kedua, penguat (transisi pertanian menuju pengembangan tanaman bernilai tinggi pada lahan yang sama). Ketiga, pengumpul (anggota keluarga pengumpul produksi, proses dan pemasaran memainkan peran dalam usaha pengembangan agribisnis berbasis keluarga); dan Keempat, pengikat golongan pengusaha (mengikat secara komplementer tetapi mandiri, pengusaha pertanian saling bekerjasama membuat sistem produksi pada lahan yang sama).

Upaya regenerasi petani di Indonesia yang dilakukan secara terencana (penyuluhan dan pemberdayaan pemuda tani) telah dilakukan sejak masa penjajahan Belanda. Bermula dari Sekolah Pertanian Rendah (SPR), kemudian menjadi Sekolah Tani Rakyat (STR) dan Kursus Pemuda Tani (KPT). Tujuannya adalah meningkatkan pengetahuan pertanian para pemuda agar menjadi petani modern yang dinamis, mudah menerima anjuran dan nasehat dari Jawatan Pertanian, sehingga para pemuda dapat menjadi kader tani di desanya. Setelah merdeka, regenerasi petani dilakukan melalui pembentukan kelompok pemuda tani-nelayan (taruna tani), Saka Taruna Bumi (Kepramukaan), pertukaran pemuda tani ke luar negeri (berpola 4-H Clubs Amerika Serikat), Sekolah Lapang PHT dan program magang (Hasansulama, 2005). Beberapa program pemberdayaan pemuda pedesaan juga diterapkan Kemenpora dan Kementan, seperti Program Sarjana Membangun Desa, Pendampingan, Indonesia Mengajar (Setiawan, 2012; Baswedan, 2012). Upaya regenerasi juga dilakukan FAO, ILO dan 
Jurnal Pemikiran Masyarakat Ilmiah Berwawasan Agribisnis. 2017. 3(2): 134-149

UNESCO (2009) melalui pemberdayaan (reinforcement) pemuda tani.

\section{Pasar Modern}

Istilah pasar dapat diterapkan pada berbagai bidang, misalnya dunia usaha, teori ekonomi, maupun pemasaran pada umumnya dan pemasaran komoditas pertanian khususnya. Pasar seringkali didefinisikan sebagai tempat bertemunya pembeli dan penjual di suatu tempat. Oleh karena itu, pasar menyangkut pembeli, penjual dan fasilitas pasar (Ratya, 2004). Pasar juga dapat diartikan sebagai tempat terjadinya penawaran dan permintaan, transaksi, tawar-menawar nilai (harga) dan atau terjadinya pemindahan kepemilikan melalui suatu kesepakatan antara pembeli dan penjual. Kesepakatan tersebut dapat berupa kesepakatan harga, cara pembayaran, cara pengiriman, tempat pengambilan atau penerimaan produk, jenis dan jumlah produk, spesifikasi, mutu produk serta kesepakatan lain yang berhubungan dengan pemindahan kepemilikan produk (Said dan Harizt, 2004).

Secara umum, pasar dapat dibagi menjadi dua kelompok besar, yaitu pasar domestik dan ekspor. Pasar yang berorientasi domestik identik dengan kualitas produk rendah serta tingkat harga yang relatif rendah. Sedangkan pasar yang berorientasi ekspor identik dengan kualitas produk yang tinggi serta tingkat harga relatif lebih mahal. Pasar ekspor yang merupakan jenis pasar modern meliputi swalayan, hotel dan restoran serta industri.

Terdapat perbedaan nyata antara pasar modern dan tradisional terutama dalam hal kestrukturan pasar yang dapat dilihat dari bangunan, suasana serta fasilitas penunjang pasar. Pasar tradisional selama ini dianggap sebagai pasar yang tidak terstruktur dengan bentuk bangunannya yang relatif sederhana dan suasana yang relatif kurang menyenangkan (ruang tempat usaha sempit, sarana parkir yang kurang memadai, kurang menjaga kebersihan pasar dan penerangannya kurang baik). Barang-barang yang diperdagangkan di pasar tradisional merupakan barang kebutuhan sehari-hari dengan mutu yang kurang diperhatikan, harga relatif murah serta cara pembelian yang menggunakan sistem tawar-menawar. Selain itu, para pedagang di pasar tradisional sebagian besar adalah golongan ekonomi lemah dengan cara berdagang yang kurang profesional. Salah satu contoh dari pasar tradisional adalah pasar Inpres.

Pada sisi lain, pasar modern merupakan pasar yang terstruktur, berada dalam bangunan modern serta 
Kajian Karakteristik, Perilaku dan Faktor Pendorong Petani Muda

Terlibat dalam Agribisnis pada Era Pasar Global

\section{ELLY RASMIKAYATI, IWAN SETIAWAN, BOBBY RACHMAT SAEFUDIN}

pelayanannya dilakukan secara mandiri (swalayan) oleh pembeli. Barang-barang yang dijual di pasar modern, selain bahan makanan seperti buah, sayuran, daging, juga barang-barang yang dapat bertahan lama. Menurut Ma'ruf (2005), gerai/pasar modern mulai beroperasi awal tahun 1960an di Jakarta. Arti modern di sini adalah penataan barang menurut keperluan yang sama atau dikelompokkan di bagian yang sama sehingga dapat dilihat dan diambil langsung oleh pembeli. Selain itu, terdapat penggunaan alat pendingin udara serta adanya pramuniaga profesional.

Macam-macam gerai/pasar modern di Indonesia adalah:

1) Minimarket, dengan pertumbuhan sebanyak 1.800 buah selama 10 tahun hingga tahun 2002. Luas minimarket antara $50-200 \mathrm{~m}^{2}$;

2) Convenience store, gerai ini mirip minimarket dalam hal produk yang dijual, tetapi berbeda dalam harga, jam buka, luas ruang dan lokasi. Convenience store ada yang buka 24 jam, dengan luas ruang antara 200-450 $\mathrm{m}^{2}$ dan berlokasi di tempat yang strategis. Sebagian produknya sedikit lebih mahal daripada yang dijual minimarket;

3) Specialty store, sebagian masyarakat lebih menyukai belanja di toko, dimana pilihan produk tersedia lengkap sehingga tidak harus mencari lagi di toko lain. Keragaman produk disertai harga yang bervariasi dari yang terjangkau hingga premium membuat specialty store lebih unggul;

4) Supermarket, pertumbuhannya sebanyak 700 buah dalam kurun 10 tahun hingga tahun 2003. Supermarket kecil mempunyai luas ruang antara 300$1.100 \mathrm{~m}^{2}$, sedangkan supermarket besar mempunyai luas $1.100-2.300 \mathrm{~m}^{2}$;

5) Departement store atau toserba (toko serba ada), gerai jenis ini mempunyai ukuran luas ruang yang beragam, mulai dari beberapa ratus meter persegi, hingga 2.000-3.000 $\mathrm{m}^{2}$;

6) Superstore, luasnya mulai dari 2.300$4.700 \mathrm{~m}^{2}$

7) Perkulakan atau gudang rabat, menjual secara grosir barang konsumsi dengan luas di atas $5.000 \mathrm{~m}^{2}$;

8) Hypermarket, dengan luas ruang > $5.000 \mathrm{~m}^{2}$.

\section{METODE PENELITIAN}

\section{Lokasi dan Waktu Penelitian}

Pemilihan lokasi penelitian berpatokan pada pembagian wilayah Priangan Jawa Barat, maka dipilih secara sengaja tiga kabupaten sampel, yakni Kabupaten Cianjur mewakili Priangan 
Jurnal Pemikiran Masyarakat Ilmiah Berwawasan Agribisnis. 2017. 3(2): 134-149

Barat, Kabupaten Bandung mewakili Priangan Tengah dan Kabupaten Garut mewakili Priangan Timur. Selanjutnya, dari tiap-tiap kabupaten ditetapkan secara sengaja tiga kecamatan sampel, masingmasing: Kecamatan Cugenang, Pacet dan Cipanas di Kabupaten Cianjur, Kecamatan Pangalengan, Ciwidey dan Pasirjambu di Kabupaten Bandung, dan Kecamatan Cikajang, Cisurupan dan Samarang di Kabupaten Garut. Penelitian utama dilaksanakan selama 15 bulan, mulai Juli 2014 sampai Oktober 2015, karena penelitian ini sudah dirintis sejak Desember 2012 hingga Maret 2013.

\section{Populasi dan Sampel Penelitian}

Unit analisis dalam penelitian ini adalah pelaku muda agribisnis terdidik sebagai individu, dengan unit observasi pelaku agribisnis di dataran tinggi. Penentuan populasi dan sampel pelaku muda agribisnis dalam penelitian ini dilakukan melalui diskusi terfokus dengan pemerintah desa, unit pelaksana teknis dan penyuluh di lokasi sampel. Metode penarikan sampel mengacu kepada teknik pengambilan sampel yang dikembangkan Slovin dengan interval kepercayaan 95 persen dan galat toleransi (e) sebesar 0,07, maka sampel untuk masing-masing lokasi penelitian $\left(\mathrm{n}_{\mathrm{i}}\right)$ dapat dihitung dengan menggunakan formula sebagai berikut:

$$
n_{i}=\frac{N}{1+N e^{2}}
$$

Dengan formula tersebut, maka diperoleh jumlah sampel (n) untuk masingmasing lokasi dengan total sampel sebanyak 280 respoden. Sampel diambil secara acak (random sample), sehingga setiap individu dalam populasi memiliki kemungkinan untuk dipilih.

Selain responden (sampel), sumber informasi dalam penelitian ini juga diperoleh dari informan yang ditentukan secara sengaja sesuai kebutuhan atau dengan menggunakan teknik bola salju (snowball) yang dimulai dari informan awal (pangkal) yang disebut juga gate keeper. Berdasarkan informasi dari informan pangkal, kemudian ditentukan informan kunci (key informan). Kemudian, dari informan kunci peneliti mendapatkan informasi mengenai informan selanjutnya yang dianggap memenuhi kriteria. Informan kunci adalah pemuda pelaku agribisnis di lokasi sampel. Informan yang direkomendasikan gate keeper mewakili empat sektor (pertanian, perikanan, peternakan dan kehutanan), empat subsistem agribisnis (upstream, onfarm, downstream dan supporting system), dan empat kelembagaan pendukung agribisnis, baik pemerintah (government), swasta 
Kajian Karakteristik, Perilaku dan Faktor Pendorong Petani Muda

Terlibat dalam Agribisnis pada Era Pasar Global

\section{ELLY RASMIKAYATI, IWAN SETIAWAN, BOBBY RACHMAT SAEFUDIN}

(businessment), akademisi (academian) maupun komunitas (community).

\section{Metode Analisis Data}

Mengacu pada Creswell (2009), penelitian ini menempatkan pendekatan kuantitatif secara dominant, sedangkan pendekatan kualitatif berposisi lessdominant. Bagi presisi generalisasi, penelitian dirancang secara kuantitatif dengan mengedepankan pendekatan survey yang diperkaya dengan Forum Discussion Group (FGD) sehingga dapat menjelaskan pengaruh dan keterkaitan antar variabel penelitian.

Untuk menjelaskan karakteristik dan perilaku pelaku muda agribisnis digunakan alat analisis deskriptif statistik dengan metode tabulasi dan ukuran-ukuran statistik lainya. Kemudian untuk menjelaskan faktor-faktor yang mendorong petani muda untuk terjun di bidang agribisnis digunakan pendekatan mix-method antara analisis data hasil survey dan hasil FGD. Data-data yang terkumpul kemudian ditabulasi, diseleksi dan dianalisis secara deskriptif, komparatif dan kolaboratif.

\section{HASIL DAN PEMBAHASAN}

Karakteristik Pribadi Pelaku Muda Agribisnis

Berdasarkan karakteristik umur petani, masih didominasi oleh petani

dewasa $(23,6 \%)$ dan tua $(44,6 \%)$. Namun demikian, jumlah petani muda dan sangat muda cukup banyak, yaitu sebanyak 89 orang $(31,9 \%)$. Para petani muda ini merupakan generasi petani yang prospektif bagi transformasi pembangunan pertanian dan pedesaan ke depan. Kemudian jika ditunjau dari tingkat pendidikannya, kebanyakan merupakan lulusan SMU/SMK umum (40\%). Yang menarik adalah petani muda dan sangat muda yang memiliki tingkat pendidikan sarjana jumlahnya sudah menembus 53\%, dengan demikian maka pelaku muda agribisnis di dataran tinggi layak disebut pelaku brain gain, karena lebih dari 50 persennya merupakan lulusan perguruan tinggi, baik sarjana umum maupun sarjana pertanian.

Selanjutnya jika dilihat dari bidang pengalaman usahanya, para petani muda dan sangat muda ini kebanyakan sudah pernah mempunyai pengalaman bergerak dalam bidang agribisnis pada sector onfarm $(41 \%)$, off-farm $(12,4 \%)$, campuran on-farm dan off-farm $(32,6 \%)$ dan sisanya di non-farm (13\%), dengan lama pengalaman pada bidang-bidang tersebut yang terbanyak adalah selama 1-2 tahun $(44,9 \%)$, kurang dari 1 tahun $(32,6 \%), 3-5$ tahun $(16,6 \%)$ dan lebih dari 5 tahun $5,6 \%$ ). Artinya, para petani muda dan 
Jurnal Pemikiran Masyarakat Ilmiah Berwawasan Agribisnis. 2017. 3(2): 134-149

sangat muda ini sudah cukup memahami aplikasi sistem agribisnis modern.

Tabel 1. Karakteristik Petani Muda dilihat dari Tingkat Pendidikannya

\begin{tabular}{lccccc}
\hline \multirow{2}{*}{ Umur } & \multicolumn{4}{c}{ Tingkat Pendidikan (Orang) } & \multirow{2}{*}{\begin{tabular}{c} 
Total \\
\cline { 2 - 5 }
\end{tabular}} \\
$\begin{array}{lccccc}\text { SMU/SMK } \\
\text { Umum }\end{array}$ & $\begin{array}{c}\text { SMK } \\
\text { Pertanian }\end{array}$ & $\begin{array}{c}\text { Sarjana } \\
\text { Umum }\end{array}$ & $\begin{array}{c}\text { Sarjana } \\
\text { Pertanian }\end{array}$ & (Orang) \\
\hline Tua (36-40 tahun) & 49 & 13 & 35 & 28 & 125 \\
\hline Dewasa (31-35 tahun) & 32 & 4 & 13 & 17 & 66 \\
\hline Muda (26-30 tahun) & 15 & 7 & 8 & 18 & 48 \\
\hline Sangat Muda (20-25 tahun) & 16 & 4 & 11 & 10 & 41 \\
\hline Total & 112 & 28 & 67 & 73 & 280 \\
\hline
\end{tabular}

Para petani generasi muda mempunyai potensi sumber daya manusia yang strategis, memiliki kemampuan ideide dan pemikiran baru untuk menciptakan sesuatu yang berbeda. Dalam rangka menyiapkan SDM petani muda yang memiliki kompetensi kerja tinggi perlu didorong kepada petani muda agar berperan aktif, kreatif dan inovatif dan tertarik dengan bidang pertanian, sehingga dapat menjadi pemicu dan pemacu sebagai motor penggerak pembangunan pertanian di Indonesia dalam era pasar global.

Tabel 2. Karakteristik Petani Muda dilihat dari Bidang Pengalaman Usaha

\begin{tabular}{lccccc}
\hline \multirow{2}{*}{ Umur } & \multicolumn{4}{c}{ Tingkat Pendidikan (Orang) } & Total \\
\cline { 2 - 5 } & $\begin{array}{c}\text { SMU/SMK } \\
\text { Umum }\end{array}$ & $\begin{array}{c}\text { SMK } \\
\text { Pertanian }\end{array}$ & $\begin{array}{c}\text { Sarjana } \\
\text { Umum }\end{array}$ & $\begin{array}{c}\text { Sarjana } \\
\text { Pertanian }\end{array}$ & (Orang) \\
\hline Tua (36-40 tahun) & 35 & 30 & 53 & 7 & 125 \\
\hline Dewasa (31-35 tahun) & 22 & 17 & 22 & 5 & 66 \\
\hline Muda (26-30 tahun) & 13 & 7 & 21 & 7 & 48 \\
\hline Sangat Muda (20-25 tahun) & 16 & 6 & 15 & 4 & 41 \\
\hline Total & 86 & 60 & 111 & 23 & 280 \\
\hline
\end{tabular}

\section{Perilaku Beragribisnis Petani Muda}

Secara keseluruhan, hampir 90\% petani menggeluti bidang pertanian, sedangkan sisanya bergelut di bidang peternakan $(6,4 \%)$, perkebunan $(3,2 \%)$ dan kehutanan (1,1\%). Petani yang menggeluti bidang pertanian sebagian besar bergerak di sektor on-farm untuk komoditas sayuran dan ada juga yang bergerak downstream, upstream dan supporting system. 
Kajian Karakteristik, Perilaku dan Faktor Pendorong Petani Muda

Terlibat dalam Agribisnis pada Era Pasar Global

ELLY RASMIKAYATI, IWAN SETIAWAN, BOBBY RACHMAT SAEFUDIN

Tabel 3. Perilaku Petani Muda dilihat dari Bidang Usaha Agribisnis yang Digeluti

\begin{tabular}{lccccc}
\hline \multirow{2}{*}{ Umur } & \multicolumn{4}{c}{ Tingkat Pendidikan (Orang) } & \multirow{2}{*}{\begin{tabular}{c} 
Total \\
\cline { 2 - 5 }
\end{tabular}} \\
\cline { 2 - 5 } & $\begin{array}{c}\text { SMU/SMK } \\
\text { Umum }\end{array}$ & $\begin{array}{c}\text { SMK } \\
\text { Pertanian }\end{array}$ & $\begin{array}{c}\text { Sarjana } \\
\text { Umum }\end{array}$ & $\begin{array}{c}\text { Sarjana } \\
\text { Pertanian }\end{array}$ & (Orang) \\
\hline Tua (36-40 tahun) & 35 & 30 & 53 & 7 & 125 \\
\hline Dewasa (31-35 tahun) & 22 & 17 & 22 & 5 & 66 \\
\hline Muda (26-30 tahun) & 13 & 7 & 21 & 7 & 48 \\
\hline Sangat Muda (20-25 tahun) & 16 & 6 & 15 & 4 & 41 \\
\hline Total & 86 & 60 & 111 & 23 & 280 \\
\hline
\end{tabular}

Selanjutnya jika dilihat dari skala usaha agribisnis petani (Tabel 4), lebih dari 52\% (146 orang) petani mempunyai skala usaha yang besar. Kelompok petani muda dan sangat muda lebih dari 60 persennya sudah mempunyai skala usaha yang besar dan sangat besar, sementara yang mempunyai skala usaha sedang ada sekitar 22,5 persen dan sisanya mempunyai skala usaha kecil $(13,5 \%)$.

Dengan mempertimbangkan

variabel-variabel di atas, menunjukkan bahwa sudah banyak para petani muda yang menggeluti usaha agribisnis terutama di sektor on-farm dengan skala usaha yang sudah cukup besar walaupun jumlahnya masih di bawah petani dewasa dan tua. Namun demikian, rasanya tidak terlalu berlebihan jika kita optimis bahwa para petani muda ini masih akan terus berkembang baik dari skala usahanya maupun jumlah petani mudanya.

Tabel 4. Perilaku Petani Muda dilihat dari Skala Usaha Agribisnis yang Digeluti

\begin{tabular}{lccccc}
\hline \multirow{2}{*}{ Umur } & \multicolumn{4}{c}{ Tingkat Pendidikan (Orang) } & Total \\
\cline { 2 - 5 } & $\begin{array}{c}\text { SMU/SMK } \\
\text { Umum }\end{array}$ & $\begin{array}{c}\text { SMK } \\
\text { Pertanian }\end{array}$ & $\begin{array}{c}\text { Sarjana } \\
\text { Umum }\end{array}$ & $\begin{array}{c}\text { Sarjana } \\
\text { Pertanian }\end{array}$ & (Orang) \\
\hline Tua (36-40 tahun) & 10 & 25 & 68 & 22 & 125 \\
\hline Dewasa (31-35 tahun) & 7 & 9 & 30 & 20 & 66 \\
\hline Muda (26-30 tahun) & 4 & 12 & 29 & 3 & 48 \\
\hline Sangat Muda (20-25 tahun) & 8 & 8 & 19 & 6 & 41 \\
\hline Total & 29 & 54 & 146 & 51 & 280 \\
\hline
\end{tabular}


Jurnal Pemikiran Masyarakat Ilmiah Berwawasan Agribisnis. 2017. 3(2): 134-149

Faktor-Faktor yang Mendorong Petani Muda Agribisnis untuk Terjun di Bidang Agribisnis

Para petani yang terjun di bidang agribinis dipengaruhi oleh faktor-faktor pendorong, yaitu faktor lembaga penyuluhan, perusahaan agribisnis, komunitas dan dukungan keluarga dengan nilai uji chi square yang signifikan. Peran lembaga penyuluhan yang dimaksud bukan hanya milik pemerintah, tetapi juga lembaga penyuluhan alternatif (swasta maupun swadaya), seperti technical services CSR dari perusahaan, tutor dari komunitas kreatif perkotaan, lembaga advokasi (sosial, bisnis, agraria, UMKM), bengkel inovasi, pekerja sosial, konsultan agribisnis, lembaga pengelola (widyaiswara) dan fasilitator sekolah lapang (SLPHT, SLIklim, SLPTT). Pada kasus di Kabupaten Cianjur, penyuluhan dilakukan dengan memanfaatkan internet (cyber) dan jaringan radio komunitas. Penyuluhan juga dilayani oleh lembaga pelatihan swadaya yang dikelola petani muda (seperti P4S). Selanjutnya, jika dilihat dari skala usaha agribisnis petani, lebih dari 52\% (146 orang) petani mempunyai skala usaha yang besar. Kelompok petani muda dan sangat muda lebih dari 60 persennya sudah mempunyai skala usaha yang besar dan sangat besar, sementara yang mempunyai skala usaha sedang ada sekitar 22,5 persen dan sisanya mempunyai skala usaha kecil $(13,5 \%)$.

Peran perusahaan agribisnis dalam mendorong para petani muda untuk terjun di agribisnis, gejalanya sudah terlihat sejak tahun 1990an, khususnya ketika korporasi agribisnis (TNCs) memulai pengiriman petugas-petugas lapangan (formulator, technical services, salesman) ke pedesaan. Seiring dengan diterapkannya pola kemitraan (contract farming), maka jumlah tenaga lapangan (yang kemudian disebut pendamping [community organizer]) pun ditingkatkan. Pada kenyatannya, petugas lapangan tidak hanya mendampingi, tetapi banyak yang mengembangkan usaha agribisnis dan tinggal menetap di pedesaan.

Dari segi faktor komunitas, saat ini tumbuh komunitas kreatif pedesaan sebagai wadah para petani muda agribisnis dan simpul koordinasi dan kolaborasi dengan berbagai pihak terkait, selain itu menguatnya modal sosial para petani muda menjadi alasan kuat nya faktor ini dalam mendorong para petani muda untuk terjun di agribisnis. 
Kajian Karakteristik, Perilaku dan Faktor Pendorong Petani Muda

Terlibat dalam Agribisnis pada Era Pasar Global

ELLY RASMIKAYATI, IWAN SETIAWAN, BOBBY RACHMAT SAEFUDIN

Tabel 5. Faktor Pendorong Petani Muda Terjun di Agribisnis

\begin{tabular}{|c|c|c|}
\hline \multirow[t]{2}{*}{ Faktor Pendorong } & \multirow{2}{*}{$\begin{array}{l}\text { Persepsi Terhadap } \\
\text { Komponen Faktor } \\
\text { Pendorong }\end{array}$} & $\begin{array}{c}\text { Jawa Barat } \\
\quad(n=280)\end{array}$ \\
\hline & & $\%$ \\
\hline \multirow[t]{5}{*}{ 1) Lembaga Penyuluhan } & (1) Tidak Mendorong & 25,71 \\
\hline & (2) Kurang Mendorong & 30,65 \\
\hline & (3) Mendorong & 35,71 \\
\hline & (4) Sangat Mendorong & 7,92 \\
\hline & Uji Chi-square (Sig.) & 0,000 \\
\hline \multirow[t]{5}{*}{ 2) Perusahaan Agribisnis } & (1) Tidak Mendorong & 26,04 \\
\hline & (2) Kurang Mendorong & 25,23 \\
\hline & (3) Mendorong & 37,69 \\
\hline & (4) Sangat Mendorong & 11,04 \\
\hline & Uji Chi-square (Sig.) & $\mathbf{0 , 0 0 0}$ \\
\hline \multirow{5}{*}{$\begin{array}{l}\text { 3) Kelompok/Asosiasi/ } \\
\text { Komunitas/ Organisasi Tani }\end{array}$} & (1) Tidak Mendorong & 29,40 \\
\hline & (2) Kurang Mendorong & 24,88 \\
\hline & (3) Mendorong & 36,22 \\
\hline & (4) Sangat Mendorong & 9,50 \\
\hline & Uji Chi-square (Sig.) & $\mathbf{0 , 0 0 0}$ \\
\hline \multirow[t]{5}{*}{ 4) Keluarga } & (1) Tidak Mendorong & 17,20 \\
\hline & (2) Kurang Mendorong & 24,05 \\
\hline & (3) Mendorong & 43,53 \\
\hline & (4) Sangat Mendorong & 15,21 \\
\hline & $\overline{\text { Uji Chi-square (Sig.) }}$ & 0,000 \\
\hline
\end{tabular}

Bagi pelaku muda terdidik dan berkeahlian yang berasal dari keluarga pelaku agribisnis dan elit-elit desa yang usahanya tergolong skala menengah dan besar, aset-aset agribisnis (seperti lahan, kandang, pabrik pengolahan, alat mesin, gudang, toko sarana produksi, tempat pembenihan [green house], rumah pengemasan [packing house], fasilitas logistik, kebun) merupakan daya tarik yang cukup besar. Bahkan, beberapa pelaku muda mengaku bahwa orang tua mereka sudah menyediakan aset agribisnis (warisan) sebelum mereka kembali dari perantauan. Hal ini menegaskan bahwa secara internal, sebagian pelaku agribisnis telah mempersiapkan proses regenerasi.

\section{PENUTUP}

Berdasarkan uraian di atas, maka dapat disimpulkan, bahwa: (1) Secara umum, karakteristik pelaku agribisnis yang muda, terdidik dan berkeahlian di 
Jurnal Pemikiran Masyarakat Ilmiah Berwawasan Agribisnis. 2017. 3(2): 134-149

dataran tinggi Jawa Barat sudah tergolong tinggi (41,76 persen) dan tidak berbeda, namun yang benar-benar mapan baru 17,59 persen. Selain muda dan terdidik, juga terlatih dan berpengalaman kerja/usaha dalam bidang non pertanian, (2) Perilaku agribisnisnya unggul, hal ini terlihat dari sudah banyaknya para petani muda yang bergerak di sektor on-farm dengan skala yang besar walaupun secara jumlah masih di bawah para petani dewasa dan tua, dan (3) Hasil analisis mengidentifikasi empat faktor pendorong yang paling dominan, yakni faktor lembaga penyuluhan, perusahaan agribisnis, komunitas dan dukungan keluarga.

Terkait dengan kepentingan regenerasi pelaku pertanian, maka rekomendasinya: (1) diperlukan peran perguruan tinggi, lembaga penyuluhan dan komunitas diaspora untuk menguatkannya, (2) perlu penguatan faktor pendorong, terutama aspek kuantitas dan kualitas layanan publik, infrastruktur, insentif dan fasilitas penunjang agribisnis di pedesaan; dan (3) agar pelaku muda agribisnis lebih siap beradaptasi, mengembangkan dan menciptakan usaha agribisnis alternatifinovatif di pedesaan, maka perlu Sekolah Lapang Wirausaha Pedesaan (SLWP) dan penguatan kepemimpinan pemuda pedesaan (rural community leader).

\section{DAFTAR PUSTAKA}

Badan Pusat Statistik. 2012. Analisis Potensi Pemuda Indonesia. Jakarta (ID): BPS.

Central Coast Mariners Academy. 2005. Youth Development. http://ccmacanada.org.

Creswell, J.W. 2009. Qualitative Inquiry and Research Design: Choosing Among Five Tradition. Sage Publications Inc. USA.

Florida, Richard. 2003. Cities and The Creative Class. New York (US): Routledge

Howkins, J. 2001. The Creative Economy: How People Make Money from Ideas. London (GB): Penguin Books.

International Labor Organization. 2008. Global Employment Trends, Update 2009. Geneva: International Labour Office. In Keles and Smith. 1974. Becoming Modern: Individual in Six Developing Countries. Massachusetts (US): Harvard University Press

Perserikatan Bangsa-Bangsa. 2002. Promoting Youth Employment", Which Calls Upon Member States 
Kajian Karakteristik, Perilaku dan Faktor Pendorong Petani Muda

Terlibat dalam Agribisnis pada Era Pasar Global

ELLY RASMIKAYATI, IWAN SETIAWAN, BOBBY RACHMAT SAEFUDIN

to Prepare National Reviews and

Action Plans on Youth

Employment. Wahington DC (US):

United Nations Programme on

Youth.

Rasmikayati. E. 2015. Dampak

Perubahan Iklim terhadap Perilaku dan Pendapatan Petani. Jurnal

Manusia dan Lingkungan, 22(3):

372-379.

Rasmikayati. E., dan Djuwendah. E. 2015. Partisipasi Petani pada Pasar

Lahan (Studi Kasus pada Petani Kentang Jawa Barat). Jurnal Agrisep, 16(1): 10-19.

Rasmikayati. E., dan Faizal. A. 2015.

Dinamika Produktivitas Padi

Ditinjau dari Fluktuasi Susut Hasil serta Faktor Sosial, Ekonomi dan

Budaya yang Mempengaruhinya.

Jurnal Agricore, 1(2): 41-52.

Setiawan I. 2012. Agribisnis Kreatif:

Pilar Wirausaha Masa Depan

Kekuatan Dunia Baru Menuju

Kemakmuran Hijau. Jakarta (ID):

Penebar Swadaya. 